\title{
LONG-TERM EFFECTS OF RIGHTS-OF-WAY MAINTENANCE VIA THE WIRE-BORDER ZONE METHOD ON BIRD NESTING ECOLOGY
}

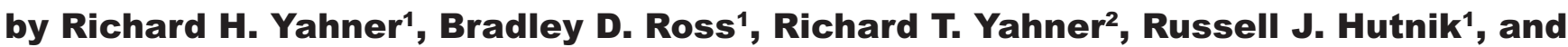 \\ Stephen A. Liscinsky ${ }^{3}$
}

\begin{abstract}
The long-term nesting ecology of birds was studied during 2002 and 2003 on the State Game Lands (SGL) 33 Research and Demonstration Area, which is located along a 230-kV transmission right-of-way (ROW) of FirstEnergy (Penelec) in the Allegheny Mountain Region, Centre County, Pennsylvania, U.S. The objectives of this study were to compare nest abundance, success, and placement (1) in handcut versus herbicide-treated study sites (units) and (2) in wire versus border zones. In addition, results from this study were compared to those obtained in a previous study conducted in 1991-1992 on the ROW to better understand the long-term effects of vegetation maintenance management on wildlife. Thirty-three and 26 nests of 10 bird species were noted in 2002 and 2003, respectively. The most frequently encountered nests in 1991-1992 and 2002-2003 were those of bird species adapted to early successional habitats, for example, eastern towhee (Pipilo erythrophthalmus), created by the wire-border zone method of vegetation maintenance on the ROW. Thirteen (39\%) of 33 nests of all species combined fledged young in 2002 compared to 17 (65\%) of 26 nests in 2003. Nesting success in 2003 on the SGL 33 ROW was typical of most studies of bird nesting success in a variety of habitats and was comparable to that recorded in 1991-1992. The low-volume basal unit was more important as nesting habitat than either handcut or mowing plus herbicide units, with nine species nesting in the low-volume basal unit versus only four species in each of the other two units. Thirtyfive $(59 \%)$ of the 59 nests on the ROW were in wire zones, whereas $24(41 \%)$ nests were in border zones. In conclusion, mowing plus herbicide treatment on a ROW may be the best application of the wire-border zone method in terms of resistance to seedling invasion of undesirable trees, cover-type development in the wire zone, and its value as wildlife habitat. Because early successional habitat is becoming less common in the eastern United States and because species dependent on these habitats are showing populations declines, the maintenance of a ROW via the wire-border zone method is extremely valuable to the long-term conservation of early successional bird species.
\end{abstract}

Key Words. Breeding birds; handcutting; herbicides; nesting ecology; rights-of-way; vegetation.

The State Game Lands (SGL) 33 Research and Demonstration Project in Centre County, Pennsylvania, U.S., has been studied since 1953, making this 51-year-old project the longest continuous project documenting the effects of mechanical and herbicidal maintenance on flora and fauna along an electric transmission right-of-way (ROW) (Yahner et al. 2002a; Vistas 2003). Transmission ROW are linear corridors that often traverse contiguous forests, thereby making these ROW extremely valuable for bird species requiring early successional habitats (Bramble et al. 1992a, 1994; Yahner et al. 2002a; Yahner 2003a). For instance, most nests found on the SGL 33 ROW in 1991-1992 were those of early successional species, including field sparrow (Spizella pusilla), gray catbird (Dumetella carolinensis), eastern towhee (Pipilo erythrophthalmus), common yellowthroat (Geothlypis trichas), and indigo bunting (Passerina cyanea) (Bramble et al. 1994).

Early successional habitat has become less common in the forests of the eastern United States in recent decades (Trani et al. 2001), and the maintenance of a ROW via the wire-border zone method creates early successional habitat for bird populations (e.g., Yahner et al. 2002b). Thus, because bird species adapted to early successional habitat have experienced population declines over recent decades in the northeastern United States (Robbins et al. 1989; James et al. 1996; Yahner 2000, 2003a; Askins 2001; Brawn et al. 2001), a ROW, if properly maintained using the wireborder zone method, represents important nesting habitat for many bird species.

In the present study, we examined the long-term response of breeding birds to ROW vegetation maintenance on SGL 33 in the Allegheny Mountain Region of central Pennsylvania in 2002 and 2003. The objectives of this study were to compare nest abundance, success, and placement (1) in handcut versus herbicidal-treated study sites (units) and (2) in wire versus border zones. In addition, results from this study then were compared to those obtained in a previous study conducted on the ROW in 1991-1992 (Bramble et al. 1994) to better understand the long-term effects of ROW maintenance on bird nesting ecology.

\section{METHODS}

The wire-border zone method of vegetation maintenance was initiated on the SGL 33 ROW in 1987 (Bramble et al. 1992a) (Figure 1). This method of vegetation maintenance along a ROW is designed to produce a tree-resistant forbgrass-shrub cover type in wire zones while simultaneously maintaining a tall shrub cover type in border zones. As a 


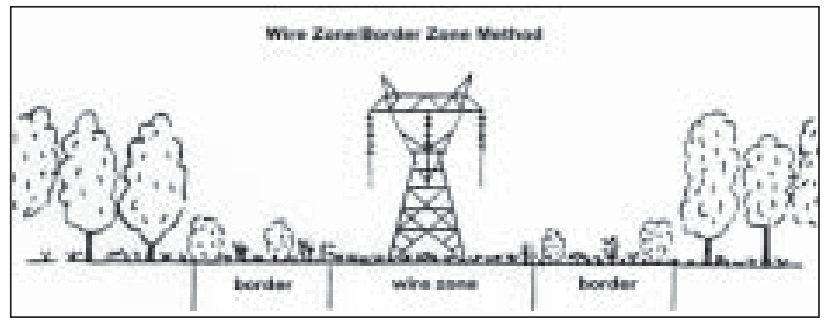

Figure 1. Diagram of a 230-kV electric transmission line, showing wire and border zones. A combination of a low-growing forb-shrub-grass cover type develops in the wire zone, and a tall shrub cover type occurs in the border zone. Adjacent to the border zone is mature forest.

result, the wire-border zone method creates a diverse wildlife habitat on the ROW, with low-lying vegetation in wire zones and taller vegetation in border zones to produce habitat diversity. The total area of wire zones was approximately equal to that of border zones.

Three major principal study sites (units) were selected for study: handcut [1.2 ha (3 ac)], low-volume basal spray [1.1 ha (2.7 ac)], and mowing plus herbicide [0.8 ha (2 ac)]. These were the same units used in a previous study of bird nesting ecology in 1991 and 1992 (Bramble et al. 1994). As time permitted, nest searches were conducted in five other units to give additional data on bird nesting ecology: two low-volume basal spray units, a mowing plus herbicide unit, a stem-foliage unit, and a foliage-spray unit.

White oak (Quercus alba) was the most abundant undesirable tree species in the handcut unit (both wire and border zones), and northern red oak (2. rubra) was the most common tree in border zones of other units (Yahner et al. 2002a). Red maple (Acer rubrum) was a minor component in handcut units, but it was an important tree species in the other units. The most important cover types were forb-grass-shrub in wire zones of all units. Shrubs were the most important cover type in border zones of all units, although forbs also were important in border zones.

In the handcut unit, woody vegetation in the wire zone was cut to a $10 \mathrm{~cm}$ (4 in.) height, and trees only were cut selectively in border zones in 2000 (Yahner et al. 2002a, 2002b). Also, in this same year, a low-volume basal spray using Garlon 4 (25\%) in basal oil (75\%) was applied in wire zones in all herbicidal-treated units to trees and tall shrubs [(including witch-hazel (Hammamelis virginiana) and bear oak (Quercus ilicifolia)] visible above the low herbaceous vegetation. The same low-volume basal spray was applied to undesirable trees in border zones, except to low-growing trees and shrubs important to wildlife (e.g., witch-hazel and bear oak).

Nest searches were conducted systematically from late May through early August 2002-2003 at 3- to 4-day intervals in the three principal units and less frequently in the other units. Two to three researchers slowly searched for nests, while watching for parental birds flushing from nests, carrying nest material, or feeding young. When a nest was found, the bird species that constructed the nest, date in which the nest was found, nest location [unit, wire versus border zone, height $(\mathrm{cm})$ above ground], substrate used for the nest, and status of the nest (number of eggs, etc.) were noted. The status of each nest was monitored at 3- to 4-day intervals to determine nesting success and was considered successful if at least one young was fledged (Yahner 1991; Bramble et al. 1994).

Nest predation is the major factor affecting nesting success in most songbird populations (Heske et al. 2001). Potential predators of nests on the ROW included snakes (Yahner et al. 2001a), white-footed mice (Peromyscus leucopus) and eastern chipmunks (Tamias striatus) (Bramble et al. 1992b; Yahner 2003b), and a variety of larger mammals (Yahner 1991; Yahner et al. 2001b). When possible, the type of predator on a nest was determined based on nest appearance and mode of disturbance (e.g., peck holes) (Rearden 1951; Yahner and Scott 1988; Hernandez et al. 1997).

\section{RESULTS AND DISCUSSION Nest Abundance and Success}

Thirty-three and 26 nests of 10 bird species were noted during 2002 and 2003, respectively (Table 1). The most frequently encountered nests were those of indigo bunting $(n=17)$, field sparrow $(n=12)$, gray catbird $(n=7)$, eastern towhee $(n=6)$, and common yellowthroat $(n=4)$. These are birds adapted to early successional habitats created by the wire-border zone method of vegetation maintenance on the ROW (Yahner et al. 2002b). These same bird species were the most common nesting species on the SGL 33 ROW in 1991-1992 (Bramble et al. 1994).

We found more nests on the ROW in 2002 than in 2003, in part, perhaps because of relatively colder ambient temperatures in 2003, which delayed plant phenology and, hence, reduced nest-site availability and concealment for breeding birds (R. Yahner, personal observation). Low ambient temperatures and resultant delays in vegetation growth can retard the onset of nest-building behavior in birds (Pettingill 1985). Similarly, fewer nests and apparent delays in nest building were observed on another ROW in southeast Pennsylvania in 2003 (Green Lane Research and Demonstration Area, Montgomery County; Yahner et al. 2003).

Only 13 (39\%) of 33 nests of all species combined fledged young during 2002 compared to 17 (65\%) of 26 nests during 2003 on the ROW (Table 1). No nests were parasitized by the brood parasite, the brown-headed cowbird (Molothrus ater) (Yahner 1995a). In 2002, a major nest predator, the eastern chipmunk, was extremely abundant regionally and was believed to have a major impact on avian nesting success on the SGL 33 ROW and elsewhere in central Pennsylvania (Yahner 2003b). How- 
Table 1. Nesting bird species and number of nests established (number of nests successfully fledging young in parentheses) in 2002 , 2003, and both years combined on the right-of-way on the State Game Lands 33 Research and Demonstration Area, Centre County, Pennsylvania.

\begin{tabular}{llll}
\hline Bird species & 2002 & 2003 & Both years \\
\hline Indigo bunting (Passerina cyanea) & $7(1)$ & $10(7)$ & $17(8)$ \\
Field sparrow (Spizella pusilla) & $7(3)$ & $5(2)$ & $12(5)$ \\
Gray catbird (Dumetella carolinensis) & $3(2)$ & $3(3)$ & $6(5)$ \\
Eastern towhee (Pipilo erythrophthalmus) & $5(2)$ & $1(1)$ & $6(3)$ \\
Common yellowthroat (Geothlypis trichas) & $4(2)$ & $1(1)$ & $5(3)$ \\
Chestnut-sided warbler (Dendroica pensylvanica) & $2(0)$ & $2(1)$ & $4(1)$ \\
American robin (Turdus migratorius) & $1(1)$ & $2(2)$ & $3(3)$ \\
Red-eyed vireo (Vireo olivaceus) & $2(1)$ & 0 & $2(1)$ \\
Veery (Hylocichla fucescens) & $1(0)$ & $1(0)$ & $2(0)$ \\
Cedar waxwing (Bombycilla cedrorum) & $1(1)$ & 0 & $1(1)$ \\
All species combined & $33(13)$ & $26(17)$ & $59(30)$ \\
\hline
\end{tabular}

per area in the mowing plus herbicide unit was $25 \%$ greater than that of the handcut unit [3.8 nests/ha/yr (1.5 nests/ac/yr)]. Thus, based on 2 years of data and results from a previous study (Bramble et al. 1994), we view the low-volume basal spray unit as the best nesting habitat and the handcut unit as the least suitable of the three units studied intensively. The low-volume basal spray unit was extremely heterogeneous in plant species composition and structure compared to handcut and mowing plus herbicide units (Yahner et al. 2002a, 2002b). Furthermore, in both years, oak sprouts, which were common in the handcut unit, leafed-out quite late compared to other species, making this plant suitable as a nest site only after mid-June. ever, nesting success in 2003 on the SGL 33 ROW was quite good, because nesting success of approximately 50\% is typical of most studies of bird nesting success in a variety of habitats (Yahner 1991).

Forty-two ( $71 \%$ of total) nests were found in the three principal treatment units (Table 2). Clearly, the low-volume basal spray unit was more important as nesting habitat than either handcut or mowing plus herbicide units, with nine species nesting in the low-volume basal spray unit versus only five species or less in each of the other two units (Figure 2). Moreover, more than twice the number of nests per area were noted in the low-volume basal spray unit [11.4 nest/ha/ $\mathrm{yr}$ (4.6 nests/ac/yr)] than in the mowing plus herbicide unit [5.0 nests/ha/yr (2 nests/ac/yr)]; in turn, the number of nests

Table 2. Nesting bird species, number of nests established in both years combined for each of the three principal treatment units, and number of nests per unit area for each unit on the right-of-way on the State Game Lands 33 Research and Demonstration Area, Centre County, Pennsylvania.

\begin{tabular}{llll}
\hline Bird species & Handcut & $\begin{array}{l}\text { Low-volume } \\
\text { basal }\end{array}$ & $\begin{array}{l}\text { Mowing + } \\
\text { herbicide }\end{array}$ \\
\hline Indigo bunting & 1 & 8 & 3 \\
Field sparrow & 0 & 6 & 2 \\
Gray catbird & 4 & 2 & 0 \\
Eastern towhee & 1 & 2 & 2 \\
Common yellowthroat & 0 & 1 & 1 \\
Chestnut-sided warbler & 0 & 3 & 0 \\
American robin & 2 & 1 & 0 \\
Red-eyed vireo & 1 & 1 & 0 \\
Cedar waxwing & 0 & 1 & 0 \\
Total number of species & 5 & 9 & 4 \\
Total number of nests & 9 & 25 & 8 \\
Number of nests/ha/yr & 3.8 & 11.4 & 5 \\
Number of nests/ac/yr & 1.5 & 4.6 & 2 \\
\hline
\end{tabular}

\section{Plants Used As Nest Sites}

Twelve plant species were used as nest sites (Table 3). The major plants used were blackberry (Rubus allegheniensis), witch-hazel, blueberry (Vaccinium spp.), and sweet fern (Comptonia peregrina). Blackberry was common in the wire zone of the low-volume basal spray unit, blueberry and sweet fern were common in wire zones of both low-volume basal spray and mowing plus herbicide units, and witchhazel was common in border zones of all units (Yahner et al. 2002a).

Indigo bunting and chestnut-sided warbler (Dendroica pensylvanica) preferred blackberry as nest sites (Table 3). Similar findings were noted in 1991-1992 on the SGL 33 ROW (Bramble et al. 1994). Indigo buntings also used relatively small $[<1 \mathrm{~m}(3 \mathrm{ft})$ in height)] witch-hazel for nest placement. On the other hand, nests of field sparrow were found most often in low-growing blueberry and sweet fern. Thus, a diversity of plant species provided suitable nest sites for a diverse breeding bird community on the ROW.

\section{Use of Wire Zones Versus Border Zones}

Thirty-five (59\%) of the 59 nests on the SGL 33 ROW were in wire zones, whereas $24(41 \%)$ nests were in border zones (Table 4). A primary reason for most nests occurring in wire zones was the presence of common nests sites (e.g., blackberry, blueberry, and sweet fern). The second most common nesting species, the field sparrow (Table 4), placed nests exclusively in wire zones; thus, if field sparrow nests were eliminated from the data set, approximately the same number of nests occurred in wire zones as in border zones (23 vs. 24 nests, respectively) (Table 4). As nesting habitat, therefore, we strongly recommend that border zones be established on a ROW, which, in combination with wire zones (Figure 1), provide abundant and diverse nest sites for the nesting bird community (Bramble et al. 1994; Yahner et al. 2002b). 
Table 3. Number of nests established per bird species in various plant species on the right-of-way on the State Game Lands 33 Research and Demonstration Area, Centre County, Pennsylvania.

\begin{tabular}{|c|c|c|}
\hline Plant species & $\begin{array}{l}\text { No. } \\
\text { nests }\end{array}$ & Bird species (no. nests) \\
\hline Blackberry (Rubus allegheniensis) & 17 & $\begin{array}{l}\text { indigo bunting (9), gray catbird (1), eastern towhee (1), chestnut-sided warbler (4), } \\
\text { red-eyed vireo (1), veery (1) }\end{array}$ \\
\hline Witch-hazel (Hammamelis virginiana) & 10 & $\begin{array}{l}\text { indigo bunting (4), gray catbird (1), eastern towhee (1), American robin (1), red-eyed } \\
\text { vireo (1), veery (1), cedar waxwing (1) }\end{array}$ \\
\hline Blueberry (Vaccinium spp.) & 8 & field sparrow (4), eastern towhee (1), common yellowthroat (2) \\
\hline Sweet fern (Comptonia peregrina) & 4 & indigo bunting (1), field sparrow (3), \\
\hline Multiflora rose (Rosa multiflora) & 3 & gray catbird (1), American robin (2) \\
\hline White oak (Quercus alba) sprouts & 3 & gray catbird (2), eastern towhee (1), indigo bunting (1) \\
\hline Meadow-sweet (Spirea alba) & 2 & indigo bunting (1), field sparrow (1) \\
\hline Chestnut oak (Q. montana) sprouts & 1 & gray catbird (1) \\
\hline Blackberry/sweet fern combined & 1 & field sparrow (1) \\
\hline Blueberry/sweet fern combined & 1 & common yellowthroat (1) \\
\hline $\begin{array}{l}\text { Hay-scented fern (Dennstaedtia } \\
\text { punctilobula)/sweet fern combined }\end{array}$ & 1 & eastern towhee (1) \\
\hline Rough goldenrod (Solidago rugosa) & 1 & field sparrow (1) \\
\hline Rough goldenrod/hay-scented fern combined & 1 & common yellowthroat (1) \\
\hline Rough goldenrod/sweet fern combined & 1 & field sparrow (1) \\
\hline Gooseberry (Ribes rotundifolium) & 1 & field sparrow (1) \\
\hline Tartarian honeysuckle (Lonicera tatarica) & 1 & gray catbird (1) \\
\hline Ground level & 1 & eastern towhee (1) \\
\hline
\end{tabular}

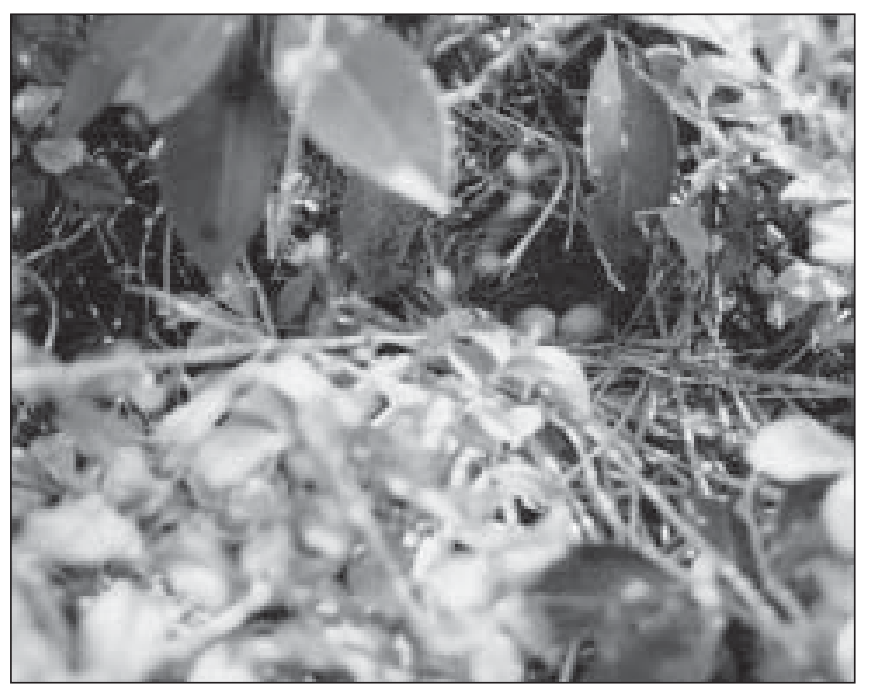

Figure 2. An eastern towhee nest in a low-volume basal spray unit (photo taken by R. Yahner, May 2002).
Table 4. Number of nests established per bird species in wire versus border zones in both years combined on the right-of-way on the State Game Lands 33 Research and Demonstration Area, Centre County, Pennsylvania.

\begin{tabular}{lcc}
\hline Bird species & Wire zone & Border zone \\
\hline Indigo bunting & 9 & 6 \\
Field sparrow & 12 & 0 \\
Gray catbird & 2 & 4 \\
Eastern towhee & 3 & 3 \\
Common yellowthroat & 2 & 3 \\
Chestnut-sided warbler & 2 & 2 \\
American robin & 2 & 1 \\
Red-eyed vireo & 0 & 2 \\
Veery & 0 & 2 \\
Cedar waxwing & 1 & 0 \\
All species combined & 33 & 23 \\
\hline
\end{tabular}




\section{CONCLUSIONS}

The State Game Lands 33 Research and Demonstration Area continues to provide nesting habitat for a variety of bird species. Native vegetation (shrubs and forbs) in both wire and border zones serves as excellent nest sites. Compared to other units, low-volume basal areas appear to be very good locations for placement of bird nests. However, given the probability of a "blackout" of electrical power if wires come in contact with tall trees, mowing plus herbicide treatment on a ROW may be the best application in terms of cover-type development in wire zones, resistance to seedling invasion of undesirable trees, and its value as wildlife habitat (e.g., Bramble et al. 1990). Cover type in mowing plus herbicide units consists of a grass-forb-shrub combination, which has restricted tree invasion to 185 trees/ha (75 trees/ac) compared to 495 trees/ha (200 trees/ ac) in other units on the SGL 33 ROW (Yahner et al. 2002a). This study and others (e.g., Bramble et al. 1992a; Yahner et al. 2002b) have shown that mowing plus herbicide is simultaneously valuable to many wildlife species.

High rates of nesting success on the ROW, particularly in 2003, attest to the fact that this linear corridor of early successional habitat does not result in a dramatic increase in rates of nest predation (Gates and Gysel 1978; Yahner 1995a, 1995b, 2000). Instead, because early successional habitat is becoming less common in the eastern United States (Trani et al. 2001) and because species dependent on these habitats are showing populations declines in recent decades (Yahner 2000, 2003a; Askins 2001; Brawn et al. 2001), the maintenance of a ROW via the wire-border zone method is extremely valuable to the long-term, regional conservation of early successional species. For instance, indigo bunting and field sparrow, which are the two most abundant species nesting on the SGL 33 ROW, are among the bird species showing significant statewide population declines according the breeding bird surveys conducted by the U.S. Fish and Wildlife Service (www.mbr-pwrc.usgs. gov/bbs/bbs/html).

\section{LITERATURE CITED}

Askins, R.A. 2001. Sustaining biological diversity in early successional communities: The challenge of managing unpopular habitats. Wildl. Soc. Bull. 29:407-412.

Bramble, W.C., W.R. Byrnes, and R.J. Hutnik. 1990. Resistance of plant cover types to tree seedling invasion on an electric transmission right-of-way. J. Arboric. 16:130-135.

Bramble, W.C., R.H. Yahner, and W.R. Byrnes. 1992a. Breeding-bird population changes following right-ofway maintenance treatments. J. Arboric. 18:23-32.
Bramble, W.C., R.H. Yahner, W.R. Byrnes, and S.A. Liscinsky. 1992b. Small mammals in plant cover types on an electric transmission right-of-way. J. Arboric. 18:316-321.

Bramble, W.C., R.H. Yahner, and W.R. Byrnes. 1994. Nesting of breeding birds on an electric utility right-ofway. J. Arboric. 20:124-129.

Brawn, J.D., S.K. Robinson, and F.R. Thompson, III. 2001. The role of disturbance in the ecology and conservation of birds. Ann. Rev. Ecol. System. 32:251-276.

Gates, J.E., and L.W. Gysel. 1978. Avian nest dispersion and fledging success in field-forest ecotones. Ecology 59:871-883

Hernandez, F., D. Rollins, and R. Cantu. 1997. Evaluating evidence to identify ground-nest predators in west Texas. Wildl. Soc. Bull. 25:826-831.

Heske, E.J., S.K. Robinson, and J.D. Brawn. 2001. Nest predation and neotropical migrant songbirds: Piecing together the fragments. Wildl. Soc. Bull. 29:52-61.

James, F.C., C.E. McCullough, and D.A. Wiedenfeld. 1996. New approaches to the analysis of population trends in land birds. Ecology 77:13-27.

Pettingill, O.S., Jr. 1985. Ornithology in Laboratory and Field (5th ed.). Academic Press, Orlando, FL 403 pp.

Rearden, J.D. 1951. Identification of waterfowl nest predators. J. Wildl. Manage. 15:386395.

Robbins, C.S., D.K. Dawson, and B.A. Dowell. 1989. Habitat area requirements of breeding forest birds of the Middle Atlantic states. Wildl. Monogr. 103:134.

Trani, M.K., R.T. Brooks, T.L. Schmidt, V.A. Rudis, and C.M. Gabbard. 2001. Patterns and trends of early successional forests in the eastern United States. Wildl. Soc. Bull. 29:413-424.

Vistas. 2003. 50 years of biodiversity research. Vistas 16(1):1-10.

Yahner, R.H. 1991. Avian nesting ecology in small evenaged stands. J. Wildl. Manage. 55:155-159.

__ 1995a. Forest-dividing corridors and Neotropical migrant birds. Conserv. Biol. 9:476-477.

_ 1995b. Forest fragmentation and avian populations in the Northeast: some regional landscape considerations. Northeast Wild. 52:93-102.

_ 2000. Eastern Deciduous Forest: Ecology and Wildlife Conservation (2nd ed.). University of Minnesota Press, St. Paul, MN. 256 pp.

_. 2003a. Terrestrial vertebrates in Pennsylvania: Status and conservation in a changing landscape. Northeastern Nat. 103:343-360. 2003b. Population trends in eastern chipmunks: Implications to avian nesting success. J. Pa. Acad. Sci. 76:62-66. 
Yahner, R.H., R.J. Hutnik, and S.A. Liscinsky. 2001a. Effect of vegetation maintenance of an electric transmission line right-of-way on reptile and amphibian populations. J. Arboric. 27:24-28.

- 2002a. 50 Years of Continuous Study: 1953-2002: State Game Lands 33 Research Project. Annual Report to Cooperators. $40 \mathrm{pp}$.

- 2002b. Bird populations associated with an electric transmission right-of-way. J. Arboric. 28:123-130.

2003. Green Lane Research and Demonstration Project: 17 years of continuous study. Annual Report to Cooperators. 28 pp.

Yahner, R.H., A.D. Rodewald, and S.C. Talbott. 2001 b. Edge-related nest predation associated with the retention of residual trees in harvested hardwood stands. Can. Field-Nat. 15:82-87.

Yahner, R.H., and D. P. Scott. 1988. Effect of forest fragmentation on depredation of artificial nests. J. Wildl. Manage. 52:158161.

Acknowledgments. Cooperators were Asplundh Tree Expert Tree Company, Dow AgroSciences, FirstEnergy (Penelec), and Pennsylvania Game Commission. A sad note-Mr. Steve Liscinsky passed away in 2003.

${ }^{1 *}$ School of Forest Resources

The Pennsylvania State University

University Park, PA 16802, U.S.

${ }^{2} 679$ Tanager Dr.

State College, PA 16803, U.S.

${ }^{3} 623$ S. Fraser St.

State College, PA 16801, U.S.

Corresponding author: Richard H. Yahner.
Résumé. Lécologie à long terme de la nidification des oiseaux a été étudiée au cours de 2002 et 2003 sur l'aire de démonstration et de recherche no 33 de State Game Lands. Cette aire est localisée le long d'une ligne électrique de transport de $230 \mathrm{kV}$ de FirstEnergy (Penelec) dans la région montagneuse des Alleghany du comté de Centre en Pennsylvanie. Les objectifs de cette étude sont de comparer l'abondance de nids et le taux de succès 1) par rapport à des coupes manuelles versus des traitements par herbicides, ainsi que 2) par rapport à la localisation - sous les fils ou en bordure de l'emprise. De plus, les résultats de cette étude ont été comparés avec ceux obtenus lors d'une étude précédente menée en 1991-92 sur ce même corridor, et ce afin de mieux comprendre les effets à long terme de la gestion du contrôle de la végétation sur la faune sauvage. Trente-trois et 26 nids de 10 espèces différentes d'oiseaux ont été dénombrés en 2002 et 2003 respectivement. Les nids les plus fréquemment rencontrés en 1991-92 et en 2002-03 étaient ceux des espèces d'oiseaux adaptées à la succession hâtive des habitats, par exemple le tohi aux yeux rouges (Pipilo erythrophtalmus), et ce grâce à la méthode employée de contrôle de la végétation au sein de l'emprise de transport. Treize (39\%) des 33 nids de toutes espèces contenaient des oiseaux avec toutes leurs plumes en 2002 comparativement à 17 (65\%) des 26 nids en 2003. Le taux de succès de nidification en 2003 au sein de l'aire 33 de State Game Lands était typique de celui de la plupart des études de nidification d'oiseaux dans une variété d'habitats et était comparable à celui enregistré en 1991-92. Trentecinq (59\%) des 59 nids dans l'emprise de transport étaient localisés dans la zone des fils alors que 24 (41\%) des nids étaient localisés en bordure de l'emprise. En conclusion, le traitement par fauchage avec herbicide dans une emprise de ligne électrique de transport serait la meilleure méthode d'intervention au sein du corridor, autant en terme de 
résistance à l'invasion par les semis d'espèces indésirables d'arbres, de développement du couvert-type dans la zone des fils électriques et de valeur de l'habitat pour la faune sauvage. Parce que la succession hâtive des habitats devient moins courante dans l'Est des États-Unis, et parce que les espèces dépendant de ces habitats montrent des déclins de leurs populations, l'entretien des emprises de lignes de transport est extrêmement importante pour la conservation à long terme des espèces d'oiseaux liées à une succession hâtive du milieu naturel.

Zusammenfassung. Von 2002 bis 2003 wurden die langfristigen Nistgewohnheiten von Vögeln auf dem Forschungsgelände des State Game Lands (SGL) untersucht, welches entlang einer 230 kV- Überlandleitung im AllegheniGebirge in Pennsylvanien liegt. Die Themen dieser Untersuchung waren der Vergleich von Nestüberfluss, Erfolg und Lage 1. in handgeschnittenen gegenüber herbizidkontrollierten Geländeeinheiten und 2. in Bereichen unter den Drähten und Grenzbereichen. Zusätzlich wurden die Ergebnisse dieser Studie mit denen einer vorherigen Studie, die 1991-92 durchgeführt wurde, verglichen, um die langfristigen Auswirkungen des Vegetationsmanagements auf das Wildleben besser zu verstehen. 33 und 26 Nester von 10 Vogelarten wurden in 2002 bzw. 2003 festgestellt. Die meisten der angetroffenen Nester in 91/92 und 02/03 waren die von Vogelarten, die sich früh an veränderte Lebensräume anpassen, z.B. Pipilo erythrophthalmus, geschaffen durch die Draht-/Grenzzonen-Methode der Vegetationsaufrechterhaltung unterhalb der Überlandleitung. 13 (39\%) der 33 Nester aller species enthielten im Jahre 2002 flüggegewordene Jungvögel, verglichen mit 17 (65\%) der 26 Nester im Jahre 2003. Im Jahr 2003 war der Nisterfolg auf der SGL 33 typisch für die meisten Studien über Vogelbrut und ließ sich daher hervorragend vergleichen mit den Studien aus 1991/92. Das niedrige Basisvolumen war als Nistplatz wichtiger als die Bestandespflege durch entweder manuellen Rückschnitt oder Herbizidkontrolle, mit 9 Vogelarten bei niedrigem Basisvolumen verglichen zu jeweils 4 Vogelarten in den beiden anderen Einheiten. 35 (59\%) von den 59 Nestern in dem Überleitungsgebiet lagen innerhalb der Drahtzone und 24 (41\%) in der Grenzzone. Schlussendlich ist Mähen plus Herbizideinsatz wohl die beste Behandlungsmethode in der Drahtzone in Bezug auf Invasion durch Samenflug unerwünschter Pflanzen, Entwicklung von deckenden Gehölzen und seinem Wert als Wildrefugium. Weil frühe sukzessive Habitate in den östlichen Vereinigten Staaten abnehmen und die davon abhängigen Species an Populationsstärke verlieren, ist die Pflege eines Hochleitungskorridors durch die Draht-/ Grenzzonen-Methode besonders wertvoll für die langfristige Arterhaltung von Vogelarten in frühen sukzessiven Habitaten.
Resumen. Se realizó un estudio a largo plazo sobre la ecología del anidamiento de las aves en el Área de Demostración e Investigación de State Game Lands (SGL) 33 durante 2002 y 2003, la cual está localizada a lo largo del derecho de vía de las líneas de transmisión de 230-kv (ROW) de la First Energy (Penelec) en la Región Allegheny Mountain, Condado Central, Pennsylvania. Los objetivos del estudio fueron comparar la abundancia de nidos, éxito y localización: (1) en sitios de estudio cortados manualmente versus sitios tratados con herbicida y (2) en zonas con alambre versus zonas frontera. Además, los resultados de este estudio fueron comparados a los obtenidos en trabajos previos conducidos en 1991-92 en el ROW para aumentar el conocimiento de los efectos a largo plazo del manejo de la vegetación sobre la vida silvestre. Treinta y tres y 26 nidos de 10 especies de aves fueron observados en 2002 y 2003 , respectivamente. Los nidos más frecuentemente encontrados en 1991-92 y 2002-03 fueron de especies adaptadas a hábitat de sucesión temprana. Por Ej. El hábitat para el ave Pipilo erythrophthalmus, creado por el método de frontera de alambre para el manejo de vegetación en el ROW. Trece (39\%) de 33 nidos de todas las especies combinadas huyeron jóvenes en 2002 comparados con 17 (65\%) de 26 nidos en 2003. El éxito del anidamiento en 2003 en el ROW SGL 33 fue el típico de la mayoría de los estudios de aves en una variedad de hábitat y fue comparable a los registrados en 1991-92. La unidad de volumen basal bajo fue la más importante como hábitat de anidamiento en comparación con las unidas cortadas manualmente o con segadora más herbicida; con nueve especies anidando en unidades de volumen basal bajo versus solamente cuatro especies en cada una de las otras dos unidades. Treinta y cinco (59\%) de los 59 nidos en el ROW estuvieron en zonas de alambre, mientras que 24 (41\%) de los nidos estuvieron en zonas de frontera. En conclusión, el tratamiento de segadora más herbicida en un ROW puede ser la mejor forma de aplicar el método de zona de frontera con alambre en términos de resistencia a la invasión de brinzales de árboles indeseables, desarrollo de tipo de cobertura en la zona de alambre y su valor como hábitat de vida silvestre. Debido a que el hábitat estacional temprano se está volviendo menos común en el este de los Estados Unidos y debido a que las especies dependientes de estos hábitat son poblaciones en declinación, el mantenimiento de una vía ROW por el método de zona de frontera alambrada es extremadamente valioso para la conservación a largo plazo de especies de aves de sucesión temprana. 